\title{
Posterior corneal folds and endothelial cell damage in human donor eyes
}

\author{
ISRAEL N NARTEY,' WILLIAM NG, ${ }^{2}$ EMIL S SHERRARD, ${ }^{2}$ AND \\ A D McG STEELE' \\ From the 'Moorfields Eye Bank, City Road, London, and the ${ }^{2}$ Department of Clinical Ophthalmology, Institute \\ of Ophthalmology, University of London, Judd Street, London WC1H 9 QS
}

SUMmaRY Posterior folds in human donor corneas stored as whole eyes in moist chambers, or isolated in McCarey-Kaufman medium at $4^{\circ} \mathrm{C}$, have been studied by light and scanning electron microscopy to determine whether or not endothelial cells on the folds are damaged. Extensive, often irreversible cell damage was found associated with most of the folds. Hence posterior folds in donor corneas are of importance in that they indirectly reduce the quality of the donor cornea for transplantation.

The condition of the corneal endothelium of human donor eyes at the time of transplantation has a great bearing upon the results of grafts for which they are used. At present the state of the endothelium is judged by slit-lamp and contact specular microscopical examination of its mosaic in the intact eye. Further assessment of McCarey-Kaufman (MK) stored corneas can be made with the Eye Bank specular microscope and video system (Product Research Organisation, Inc Tustin, California, USA) immediately before grafting while the excised cornea is in the preservation medium.

Posterior corneal folds are a well known clinical manifestation of overhydration of human corneas. They have been reported in intact donor eyes ${ }^{1}$ and in isolated corneas mounted under the specular microscope. ${ }^{2}$ They are not apparent, however, in corneas less than two hours post mortem. There is some evidence that endothelial cells incorporated in the folds are damaged-for example, they take up silver nitrate and trypan blue ${ }^{34}$-and show morphological changes in a variety of species.

Recently Alfonso et al. . $^{5}$ coined the term 'snailtracks' to describe irregular, discontinuous, greyish white streaks or patches seen at the level of the corneal endothelium in patients after surgical procedures in the anterior chamber. They stated that these tracks could be differentiated easily from Descemet's folds. They noted a similar phenomenon in donor corneas stored in MK medium. From their scanning Correspondence to Dr I N Nartey, Moorfields Eye Hospital, City Road, London EC1V 2PD. electron microscopic (SEM) finding of tracks of damaged endothelial cells in the donor corneas they suggested that clinical snailtracks may have relevance as a marker for corneal endothelial cell damage. Investigation of clinical snailtracks by Laganowski and associates ${ }^{6}$ failed to reveal significant cell damage. Thus it seems that the tracks seen in corneas in vivo and in vitro are not the same. Endothelial cells on the sloping sides of the posterior folds of donor corneas are invisible to the specular microscope. Therefore in the present study relationships between cell damage and the folds were sought by scanning electron microscopy.

\section{Material and methods}

Two paired and four unpaired donor eyes received at the Eye Bank were used for this study. The ocular history was normal in each. All were examined with the slit-lamp and wide field specular microscope (the Pocklington, Keeler/Konan) for the presence of folds. The paired eyes ( 1 and 2 in Table 1$)$ were enucleated 15 hours post mortem and stored intact for four hours in moist chambers at $4^{\circ} \mathrm{C}$ before their corneas were excised, with a $2 \mathrm{~mm}$ scleral rim, and placed in MK medium at $4^{\circ} \mathrm{C}$ for 96 hours. The remaining eyes, nos. $3,4,5$, and 6 (Table 1), were left intact suspended in a moist chamber at $4^{\circ} \mathrm{C}$-one each for $24,48,110$, and 120 hours-before corneoscleral buttons were prepared as above.

After their storage in MK medium the paired corneas and the one prestored for 110 hours in a 
Table 1 Donor information

\begin{tabular}{|c|c|c|c|c|c|c|c|}
\hline Eye & $\begin{array}{l}\text { Age } \\
\text { (yr) }\end{array}$ & Sex & $C O D$ & $\begin{array}{l}\text { Death to } \\
\text { Enucleation }\end{array}$ & $\begin{array}{l}\text { *Enucleation to } \\
\text { SL exam }\end{array}$ & $\begin{array}{l}\text { Time in } M C \\
\text { at } 4^{\circ} \mathrm{C}\end{array}$ & $\begin{array}{l}\text { Time in } M K \\
\text { at } 4^{\circ} \mathrm{C}\end{array}$ \\
\hline 1 & 79 & $\mathbf{M}$ & Bronchopneumonia & $15 \mathrm{~h}$ & $2 \cdot 5 \mathrm{~h}$ & $4 \mathrm{~h}$ & $96 \mathrm{~h}$ \\
\hline 2 & 79 & $\mathbf{M}$ & Bronchopneumonia & $15 \mathrm{~h} 10 \mathrm{~min}$ & $2 \cdot 75 \mathrm{~h}$ & $4 \mathrm{~h}$ & $95 \cdot 5 \mathrm{~h}$ \\
\hline 3 & 63 & $\mathbf{M}$ & Myelodysplasia & $2 \cdot 25 \mathrm{~h}$ & $3 \mathrm{~h}$ & $24 \mathrm{~h}$ & - \\
\hline 4 & $7 / 52$ & $\mathbf{M}$ & Cot death & $4 \cdot 5 \mathrm{~h}$ & $2 \mathrm{~h}$ & $48 \mathrm{~h}$ & - \\
\hline 5 & 76 & $\mathbf{F}$ & Carcinoma liver & $8 \mathrm{~h}$ & $3 \mathrm{~h}$ & $110 \mathrm{~h}$ & - \\
\hline 6 & 80 & $\mathbf{M}$ & Cerebrovascular accident & $9 \mathrm{~h}$ & $3 \mathbf{h}$ & $120 \mathrm{~h}$ & - \\
\hline
\end{tabular}

* Enucleation to slit-lamp examination.

$\mathrm{MC}=$ moist chamber .

MK = McCarey Kaufman medium.

$\mathrm{COD}=$ cause of death.

moist chamber were fixed in gluteraldehyde $(3 \%, \mathrm{pH}$ $7 \cdot 2)$, postfixed in buffered osmium tetroxide $(1 \%)$, dehydrated in ascending graded alcohols, critical point dried, and their endothelial sides sputter coated with gold for examination in a Hitachi S520 scanning electron microscope at $20 \mathrm{kV}$.

The endothelia of the remaining corneas were removed, flat mounted on glass slides, stained with silver and celestine blue according to the method of Smolin, ' and examined with the light microscope.

\section{Results}

Slit-lamp examination of the corneas of the six human donor eyes at the post-mortem times before storage shown in Table 1 revealed moderate to severe
Fig. 1 Photomicrograph of endothelial flatmount of 7-week-old cornea showing two rows of cells with incorporated silver in an otherwise normal mosaic. Silver and celestine blue. $\times 150$.

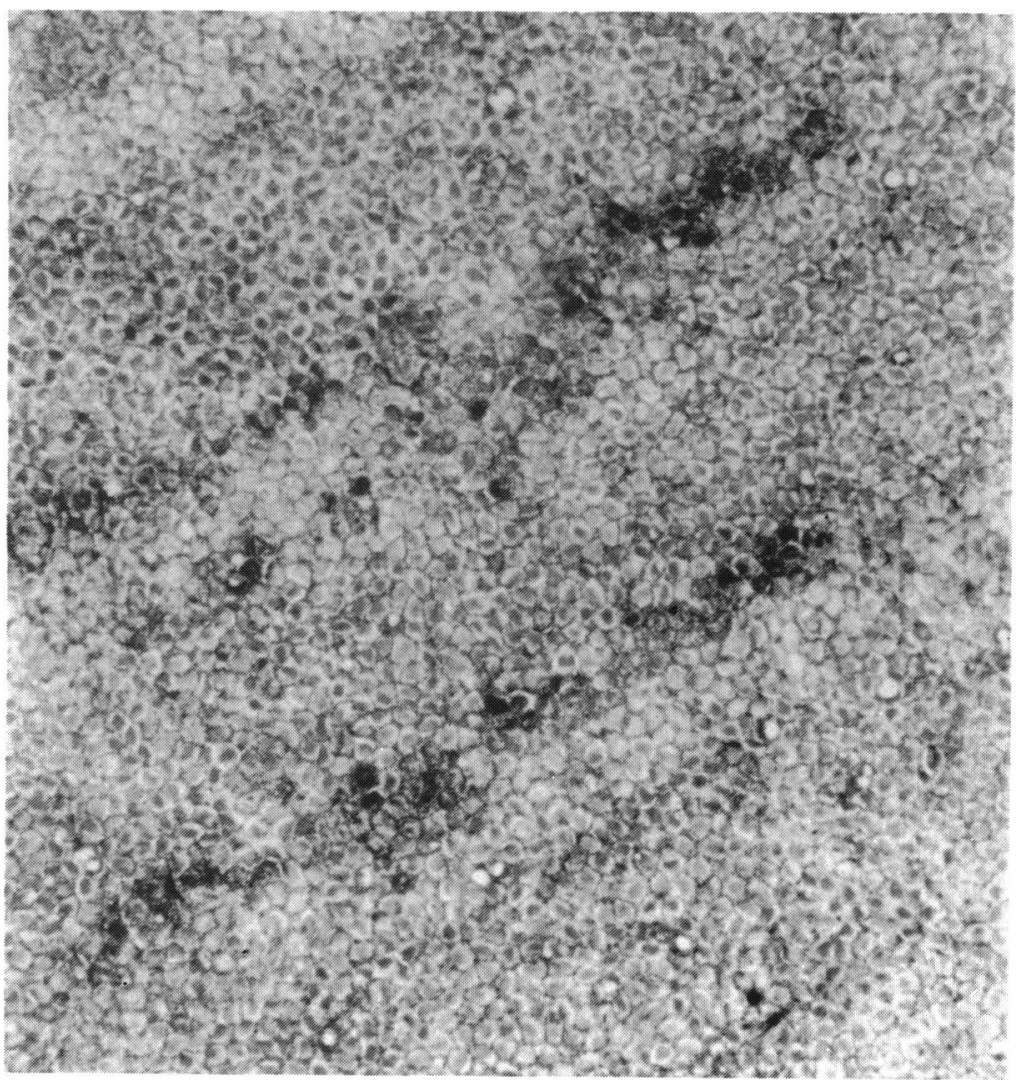


stromal oedema and crisscrossing folds in all quadrants at the level of Descemet's membrane. The folds appeared as greyish white curvilinear opacities in direct illumination or as fine glistening striae in specular reflection. Some of them spanned the entire diameter of the cornea and others extended only from the periphery to the centre. In the 7-week-old cornea (no. 4, Table 1), the folds appeared as parallel lines in contrast to their curvilinear configuration in the adult corneas. Slit-lamp examination of folds at intervals during moist chamber storage showed that they became more numerous with increasing storage time.

\section{SPECULAR MICROSCOPY}

Visibility of the endothelium with the specular microscope was limited to small, discontinuous areas between folds on all occasions, and the clarity of the image was reduced by stromal oedema. Visible cells appeared normal with some polymegethism in the older eyes.

\section{LIGHT MICROSCOPY}

In the silver 'stained' endothelial flat mounts there were large areas of apparently normal cells with metallic silver confined to the intercellular spaces. There were also bands of cells which were impregnated with silver (Fig. 1), which indicated permeability (and damage) of the cell membranes to silver nitrate. The dimensions and orientations of the bands of cells resembled those of the posterior corneal folds seen before removing the endothelium.

\section{SEM}

Obvious features with low magnification SEM were ridges of the posterior corneal surface (Fig. 2). These were considered to be the folds seen with the slitlamp because their orientations were similar. At higher magnification (Fig. 3) most of the cells away from the folds appeared intact and normal, though a few showed raised central areas (nuclear humps) and partial loss of cell outlines. However, the cells in two or three rows along the crest of most of the folds were apparently irreversibly damaged. Along the major portions of the fold the cell borders were indistinct, the posterior membranes were fragmented, and the cyptoplasm was apparently condensed into irregular granules. At the end of the folds surface damage was less marked. The cell borders were still distinguishable and the posterior membranes appeared intact, yet they were deeply indented centrally (Fig. 4) and resembled the denucleated cells described by George, Sourdille, and Bonnaillie. ${ }^{8}$

\section{Discussion}

A number of investigators have studied the human

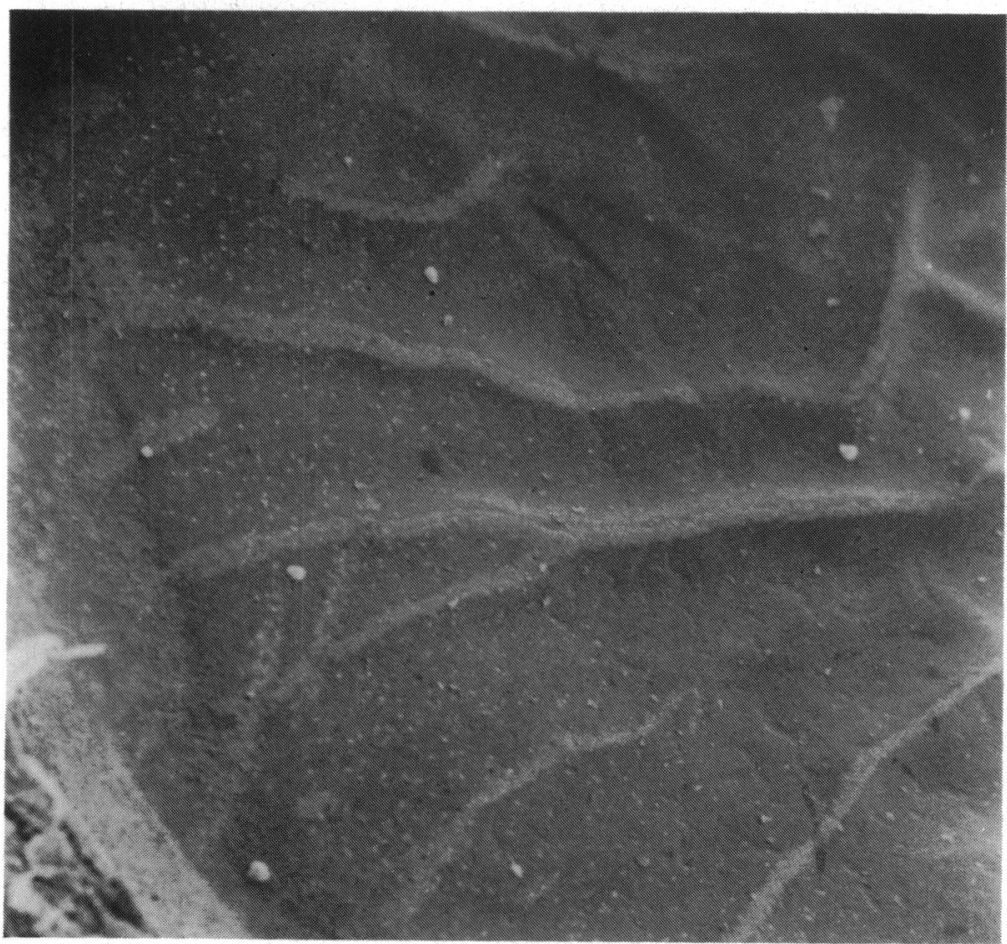

Fig. 2 Scanning electron micrograph (SEM) of specimen 2 showing folds or ridges in the posterior cornea. $\times 35$. 
Fig. 3 Higher magnification SEM of one of the folds in Fig. 2: with irreversibly damaged cells along the crest of the fold and apparently normal cells away from the fold. $\times 590$.

Fig. 4 SEM of specimen 2 showing 'denucleated' cells towards the end of a fold. $\times 590$.
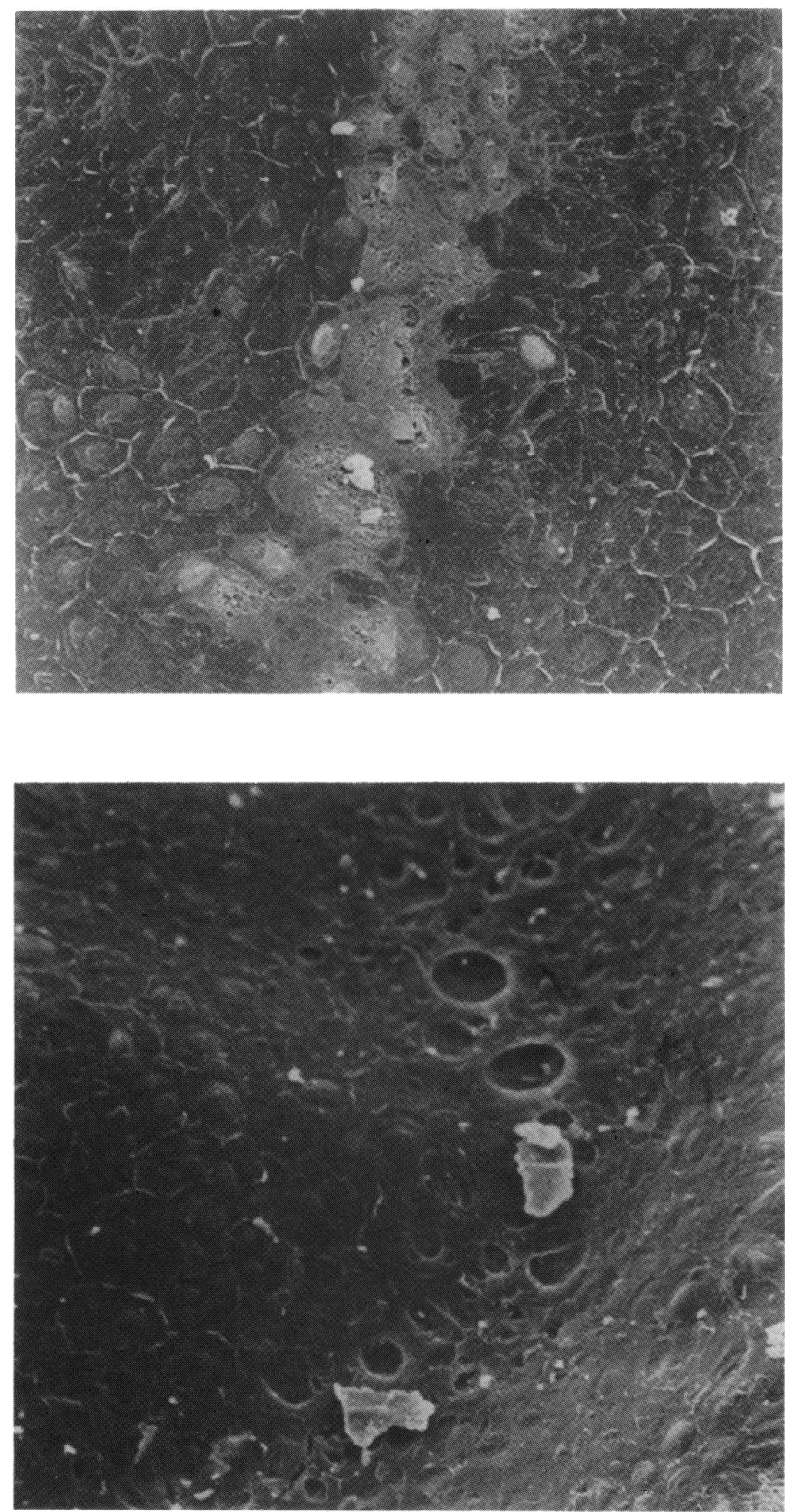
corneal endothelium by $\mathrm{SEM}^{9-12}$ and a normal appearance has been established. The few studies of cells incorporated in posterior folds describe varying degrees of cell damage. ${ }^{34}$ They and the present study confirm that damaged or dead cells are associated with folds in the posterior layers of corneas in vitro. It follows that, if folds are numerous, the quality of the corneas for transplantation is reduced.

Alfonso et al. ${ }^{5}$ assumed that the snailtracks seen in vivo and in vitro were the same and that folding was not involved. Laganowski et al. ${ }^{6}$ found clinical snailtracks to be small folds (wrinkles) with minimal cell damage. Hence it appears that folding in one instance is associated with cell damage and is not in another, and it seems reasonable to assume that either the mechanics of fold formation are different in vivo and in vitro-and result in significant cell damage in the latter only-or that the additional stresses of 'handling' the donor corneas irreversibly damage cells already weakened by the post-mortem folding.

The folds in the posterior layers of donor corneas are undoubtedly a result of post-mortem hydration of the corneal stroma, but the precise reason for their formation is unknown. Roozitalab and colleagues ${ }^{13}$ described striae-which are not considered to be synonymous with folds -in donor corneas and believed that they were caused by stretching forces during excision of the corneoscleral button. Grutzmacher et al. ${ }^{14}$ compared two excision techniques with regard to severity and incidence of endothelial striae and demonstrated that excessive traction results in cell damage or death. In the present study folds were seen with the slit-lamp and specular microscope in all intact donor eyes before careful excision of the corneoscleral buttons. Therefore excessive traction cannot be implicated as the primary cause of the folds. Since, however, the nature of damage to endothelial cells induced by excessive traction by Grutzmacher and associates was similar to that observed by us on the folds in some corneas, without traction, it seems reasonable to suggest that there are at least two mechanisms of inducing endothelial cell damage in donor corneas: (a) as a result of the formation of post-mortem folds in the posterior layers of corneas, and $(b)$ from excessive traction during excision of donor corneoscleral buttons.

If the maximum number of endothelial cells is to be preserved on donor corneas, it would seem desirable to seek methods to eliminate corneal folding, which itself damages cells, and to avoid traction and distortion of the corneas during excision, which aggravates damage of cells on folds or in the positions of their potential formation. However, there is still no substitute for the freshest donor material possible, and stored material will always inevitably be second best.

We thank Mrs $\mathrm{H}$ Taylor for typing the manuscript and the Department of Medical Illustration for the photographic processing.

\section{References}

1 Archer DB, Trevor-Roper PD. Organisation and administration of Westminster-Moorfields Eye Bank. Br J Ophthalmol 1967; 51: 1-12.

2 Hodson S, Wigham C, Williams L, Mayes KP, Graham MV. Observations on the human cornea in vitro. Exp Eye Res 1981; 32: 353-60.

3 Neubauer L, Laing RA, Leibowitz HM. Specular microscopic appearance of damaged and dead endothelial cells in corneas following short-term storage. Arch Ophthalmol 1984; 102: 439-44.

4 Singh G, Böhnke M, von-Domarus D, Draeger J, Lindstrom RL, Doughman DJ. Vital staining of corneal endothelium. Cornea 1985; 4: 80-91.

5 Alfonso E, Tucker GS, Battle JF, Mandelbaum S, Gellender H, Forster RK. Snailtracks of the corneal endothelium. Ophthalmology 1986; 93: 344-9.

6 Laganowski HC, Kerr Muir MG, Sherrard ES. Postoperative grey white lines of the posterior cornea and endothelial cell damage. Br J Ophthalmol 1987; 71: 877-83.

7 Smolin G. A technique for staining and separating corneal endothelium. Am J Ophthalmol 1968; 65: 232-6.

8 George Y, Sourdille PH, Bonnaillie. Cornea. In: Hervouet F, Ertus M, eds. Scanning electron microscopic studies of the eye structures. Paris: Masson, 1973: 5-13.

9 Blumke S, Morgenroth K. The stereo ultrastructure of the external and internal surface of the cornea. $J$ Ulstrastruct Res 1967; 18: 502-18.

10 Maclean H, Haining WH. Scanning electron microscopy of cornea. Trans Ophthalmol Soc UK 1971; 91: 31-40.

11 McCarey BE, Sakimoto T, Bigar F. Ultrastructure of M-K and refrigerated moist chamber stored corneas. Invest Ophthalmol Vis Sci 1974; 13: 859-63.

12 Davies RP, Kirkham JB, Villaneuva S. Surface ultrastructure of human donor corneal endothelium. Trans Ophthalmol Soc UK 1976; 96: 96-104.

13 Roozitalab MH, Requard J, Fogle JA, Green WR, Graham CR. Endothelial stretch striae in donor cornea. Cause, significance and prevention. Maryland State Med J 1979; 28: 47-55.

14 Grutzmacher RD, Oiland D, Makillop BR, Bunt-Millam AH. Donor corneal endothelial striae. Am J Ophthalmol 1986; 102: 508-15.

Accepted for publication 11 February 1988. 